\title{
Integrated local development in Mediterranean marginal territories: The case studies of Casentino (Italy), Algarve (Portugal) and Corse (France)
}

\author{
Andrea Ricci ${ }^{1}$, Mario Biggeri ${ }^{1,2}$, Andrea Ferrannini ${ }^{1,3}$ \\ ${ }^{1}$ ARCO (Action Research for CO-development), PIN Scrl, Prato, Italy \\ ${ }^{2}$ University of Florence, Florence, Italy \\ ${ }^{3}$ University of Ferrara, Ferrara, Italy \\ Received: 21 September 2017/Accepted: 17 October 2018
}

\begin{abstract}
Today, Mediterranean marginal territories are facing tremendous challenges. In the last decades, they have been characterised by a progressive abandonment in favour of urban areas, with consequent high social and environmental costs, such as the hydrogeological instability, degradation and soil erosion. However, at the same time they have relevant endogenous resources, which are often underutilized and unexploited and could be pivotal both for their strategic recovery, as well as for the economic and social development of the whole European Union.

This research investigates the potential active role of Mediterranean "marginal territories" to the achievement of the visions underlying the Europe 2020 strategy for smart, sustainable and inclusive growth. This paper aims to verify the idea that Mediterranean marginal and weak areas could lead their own development trajectories and, at the same time, actively contribute to harmonious development processes in Europe. The structure of this paper starts from general theoretical arguments and a short description of European policies for development. It follows with the diagnostic analysis of three territorial contexts selected as case-studies, i.e. Casentino (Italy), Algarve (Portugal) and Corse (France). Finally, it comes back to the general issues proposing implications and lessons learnt for the promotion of sustainable human development in Europe.
\end{abstract}

Key words: European and Mediterranean marginal territories, sustainable human development, territorial cohesion, Casentino, Algarve, Corse

\section{Introduction}

The importance of the relationship between territory and human development is undeniable in every historical phase, and in every place where human beings live. This relationship sees the territory as the dynamic and stratified result of a complex system of relations between living communities and the environment (Becattini 2014).

However, every development process creates territorial disequilibria and imbalances, with marginal territories often excluded from innovation processes and global knowledge networks due to their low competitiveness, capacities and accessibility. This marginality - especially in the case of inland and mountainous areas - often creates structural and long-term weaknesses, leading vicious cycles of abandonment and exclusion. 
Marginal and weak territories in Europe, especially in mountainous and inland areas, have been historically characterised by a long and progressive abandonment in favour of urban areas, with consequent high social and environmental costs such as hydrogeological instability, degradation and soil erosion. The demographic decline coincides with the weakening of the supply of basic social services. In other words, "Europe is facing increasing and territorially differentiated challenges, and the risk of social exclusion is higher in areas with low accessibility, weak economic performance and lack of opportunities" (EU 2011, p. 5). Moreover, as clearly explained by Rodríguez-Pose (2018), persistent poverty, economic decay and lack of opportunities are at the root of considerable discontent in declining and lagging-behind areas, leading to the belief that these places have "no future" and "don't matter".

These marginal and weak territories are thus facing tremendous challenges, but at the same time they offer important potential for human development (UNDP 1990, Sen 1999) that must be exploited in order to find new trajectories for the human flourishing in Europe. Indeed, these areas are endowed with relevant endogenous resources - i.e. social, human and natural capital - that are often underutilized and unexploited, but could be pivotal both for their strategic recovery, as well as for the economic and social development of the whole European Union. Therefore, finding appropriate development trajectories for such areas could generate important benefits for a more harmonious development in Europe, strengthening cohesion and sustainability in economic, social and environmental terms. However, this could happen only if territories are able to propose ideas, models or development processes that are in relation to those of core areas and thus with other local development systems, in a necessary and mutual exchange of ideas, competences and services. In other words, if better policies are implemented focusing on tapping into untapped potential and on providing opportunities to those people living in the places that "don't matter" (Rodríguez-Pose 2018, p. 189).

The research hypothesis underlying this paper is that, in a reality dominated by global markets and territorial disequilibria, local systems in marginal territories still have, at least in the European context, the potentialities to take actively part at development processes, and not simply to survive in the global competitive environment. This perspective could be useful also to assess the effectiveness of multi-level relations between supranational policies (i.e. Agenda 2030, Europe 2020 with its Territorial Agenda and Cohesion Policy, etc.), national strategies and local development processes. In this regard, the Territorial Agenda of the European Union 2020 opened an important debate on the territorial dimension of policies and strategies. This Agenda provides a strategic orientation for territorial development and considers the Europe 2020 goals achievable only if the territorial dimension of the strategy is taken into account, arguing that "the diversity of territories is a potential for development and that the distinctive identities of local and regional communities are of key relevance in this regard" (EU 2011, p. 4).

Nowadays, it is therefore critically important to sustain renewed momentum around the long-term structural shifts required to meet the goal of the Europe 2020 strategy and the Agenda 2030 for Sustainable Development, especially in territories with marginal and peripheral characteristics, such as inland and mountainous areas.

The general objective of this paper is to investigate the potential active role of "marginal territories" to the achievement of the visions underlying the Europe 2020 strategy for smart, sustainable and inclusive growth. After this introduction, the paper is structured as follows. The second part is dedicated to a literature review on the relation between territories and human development and on the theoretical, interpretative framework on sustainable human development at local level. The third part contextualises the European policy framework for development in marginal and disadvantaged areas, while the fourth part describes the research design and the methodology used for data collection and analysis. The fifth part presents the results of the diagnostic analysis of three local development systems selected as case-studies due to their features of marginality and structural weaknesses: Casentino (Italy), Algarve (Portugal) and Corse (France). Based on this analysis, the sixth part highlights specific strategic actions to overcome the condition of marginality and to pursue sustainable human development trajectories. The last part summarises the final remarks and future perspectives. 


\section{The relationship between territory and human development}

The relationship between territory and human development is at the centre of the theoretical framework underlying this paper. Among many, we consider Raffestin's definition of human territoriality as the more adequate for our purposes: "a complex system of relationships linking individuals or/and social groups with territory (exteriority) and with others (alterity) by means of mediators (instruments, techniques, representations etc.), in order to guarantee a maximum of autonomy within the limits of the system" (Raffestin 1980). Thus, Raffestin argues that the territory is generated starting from the relation between society and space, as actors "territorise" space.

In the last decades, concepts like "local development systems", "endogenous potential" and "local public goods" have acquired a central place in the academic literature due to the debate in economic geography and regional studies. According to Amin (1999), the idea at the base of local development is "to unlock the "Wealth of regions" as the prime source of development and renewal [...] in tending to favour bottom up, region specific, longer term and plural-actor based policy action" (Amin 1999, p. 368). In line with this reasoning, Pike et al. (2007, p. 1263) define development as the "establishment of conditions and institutions that foster the realization of the potential of the capacities and faculties of the human mind in people, communities and, in turn, places". This underlines also the territorial and people-centred perspective on Sustainable Human Development advanced by Biggeri, Ferrannini (2014), based on the recognition that the territory where individuals live and interact has fundamental importance for expanding or reducing economic and social capabilities, agency and empowerment. Therefore, these authors define Sustainable Human Development (SHD) at the local level as "a process of enabling the local system to function in order to facilitate the expansion of the real freedoms that people enjoy in an integrated and sustainable manner" (Biggeri, Ferrannini 2014, p. 147).

Moreover, the place-based approach to development strategies (Bolton 1992, Barca 2009) gives emphasis to the territorial context (in social, cultural and institutional terms), to multi-stakeholder and the interactive construction of knowledge in order to reinforce community capabilities and promote innovative ideas for the design of public policies and the tailored provision of public goods. In line with this argument, it is necessary to make development interventions more "place-aware" or "place-sensitive" by "taking into consideration the sheer variety of factors in diverse geographical location which may affect the potential returns of intervention" (Barca et al. 2012, p. 136). Nonetheless, the development of local systems is often based, through links between sectors and territories, on initiatives and actions taken in other places or by external institutions/agents (Becattini 2001). Therefore, it is crucial to recognise that local development does not simply depend on local efforts, but effective development trajectories can be pursued only if various levels are involved and aligned toward the achievement of common goals (Biggeri, Ferrannini 2014). In this regard, multilevel governance indicates the novel form of making public policy, due to the existence of "overarching, multilevel policy networks" (Marks 1996, p. 167), and could be understood as "a panoply of systems of coordination and negotiation, among formally independent but functionally interdependent entities" (Piattoni 2010, p. 26). The policy process must therefore be understood as an approach where local elites and endogenous actors interact with the external agents involved in the policies (Barca 2009). The importance of multi-level articulation lies in the ability to valorise endogenous resources by involving and including local stakeholders along with linking them with initiatives, resources and competences coming from other territories and higher governance levels. All in all, these arguments lead us to embrace an integrated approach for territorial diagnostics and analysis, taking into account, among others: socio-economic conditions; geography (density and accessibility); international global-local linkages; local, regional, national and communitarian policies for investment and innovation (Storper 1997, Pike et al. 2007, Crescenzi, Rodríguez-Pose 2011). The most innovative feature of this approach is thus the call for an integration of different levels of analysis, which have been historically separated and not treated with a systemic approach in a unique framework (Rodríguez-Pose, Crescenzi 2008), e.g. macro and micro economic theories with meso-level 
or regional ones; quantitative and qualitative analyses; top-down and bottom-up policy approaches. In particular, reconciling top-down and bottom-up development policies is necessary and critical to effectively foster sustainable human development at local level (Biggeri, Ferrannini 2014).

This integrated approach is appropriate to analyse the object of this paper - i.e. marginal and weak territories - and their endogenous potential. In theoretical terms, the idea of marginality is directly linked to the centre/periphery relation and to the issues of accessibility due to geographical, infrastructural, social and cultural factors. Marginality is mostly measured through simple quantitative parameters, such as the distance from agglomeration centres, often used in socioeconomic research on mountainous and inland areas.

The concepts of geographical and socio-economic marginality are also often correlated with the different types of weaknesses that may characterize a territory: e.g. weak as a consequence of human abandonment dynamics; weak as a consequence of absence of primary resources, services and capacities; weak in the sense of isolated, little, unknown and forgotten. These issues often require more complex quantitative-qualitative parameters that gravitate around the central elements of endowments, governance and capacities, as it will be discussed in the analysis of our case-studies.

\section{European development policies for marginal territories}

A large part of the European territory is characterised by the aggregation of citizens in minor centres, with limited accessibility to essential services. Since the War World II, the inland areas have been gradually and progressively subject to a process of marginalization characterised by demographic decrease, weakening of the supply of local basic services, high social cost for the whole country such as the hydrogeological instability and the environmental and cultural degradation (Dematteis 2013). In other words, as stated by Rodríguez-Pose (2018, p. 205), "years of decline, lack of opportunities and perceived neglect have put lagging-behind and declining areas in a state of flux".

For this reason, it is important to briefly recap the main development policies and instruments for marginal areas implemented by the EU with clear territorial objectives implications (in particular, the Cohesion Policy), in order to detect the evolution of the territorial dimension along with the integration process.

To begin with, it should be noted here that the Common Agricultural Policy and the Cohesion Policy are conceived to be the main EU "development instruments", allowing to better focus on specific objectives and making more efficient the sectorial policies through integrated actions, in line with the European Treaties (Rome, 1957; Maastricht, 1992; Amsterdam, 1997; Nice, 2001; Lisbon, 2007) and with the most recent Europe 2020 Strategy (see Table 1). Indeed, cohesion and convergence of the less developed areas have been regarded as a precondition for the competitiveness of the European Union as a whole.

Central attention needs to be paid to the EU Cohesion Policy as well as to the EU Rural Development Policy, as they both aim at promoting wellbeing and socio-economic stability for all the communitarian citizens, by investing on people and territories. Moreover, both policies are built on a multi-level governance mechanism (see Table 2) and on the participation of all the involved actors in development processes.

It is also important to briefly recap the evolution of the EU Cohesion Policy over the years. Indeed, the Cohesion Policy remains the main investment policy of the European Union and it is also the main policy tool to quickly answer to important crisis situations, directing funds where are more needed, and to sectors with high employability and growth rates.

Since the Rome Treaty of 1957, one of the main tasks of the Community has been to promote a "harmonious development of economic activities", by aiming "at reducing the disparities between the levels of development of the various regions" (Treaty of Rome, 1957). The need for a coordinated Community solution to regional imbalances was also recognized in the 1965 First Communication on Regional Policy. Thus, the idea of structuring aid for deprived regions started taking shape in the late 1960s, with the 
Table 1: The Europe 2020 Strategy: Axes and Targets

\begin{tabular}{|c|c|}
\hline Priorities Axes & Main Targets \\
\hline $\begin{array}{l}\text { a Smart growth: developing an } \\
\text { economy based on knowledge and } \\
\text { innovation through more effective } \\
\text { investment in education, research } \\
\text { and innovation; } \\
\text { b Sustainable growth: promoting } \\
\text { a more resource efficient, greener } \\
\text { and more competitive economy } \\
\text { decoupling economic growth from } \\
\text { resource use thanks to a decisive } \\
\text { move towards a low-carbon } \\
\text { economy; }\end{array}$ & $\begin{array}{l}\text { 1. Employment: } 75 \% \text { of the } 20-64 \text { year-olds to be em- } \\
\text { ployed; } \\
\text { 2. R\&D: } 3 \% \text { of the EU's GDP to be invested in Research } \\
\text { and Development activities; } \\
\text { 3. Climate change and emission sustainability } \\
\text { " } 20 / 20 / 20 \text { ": } \\
\text { a Greenhouse gas emissions } 20 \% \text { lower than in } 1990 \text {; } \\
\text { b } 20 \% \text { of energies from renewables. } \\
\text { c } 20 \% \text { increase in energy efficiency. } \\
\text { 4. Education: } \\
\text { i Reducing the rates of early school leaving below } \\
10 \% \text {; } \\
\text { ii At least } 40 \% \text { of the } 30-34 \text {-year-olds completing the } \\
\text { third level education; } \\
\text { 5. Fighting poverty and social exclusion: at least } 20 \\
\text { million fewer people in or at-risk poverty and social } \\
\text { exclusion. }\end{array}$ \\
\hline
\end{tabular}

Source: EC (2010)

Table 2: Multi-level Governance of the Planning Cycle 2014-2020

\author{
Communitarian Level \\ STRATEGIC COMMON FRAMEWORK \\ National Level \\ Partnership Agreement (PA) \& National Operative Programme (PON) \\ Regional Level \\ Regional Operative Programmes (POR) \& Rural Development Programmes (PSR)
}

Source: Author's elaboration

creation of the Directorate General for Regional Policy, which considered the support to underdeveloped regions "as important as the heart in the human body" and able to reanimate human life in the areas which have been denied it (Jean Rey, speech at the Directorate General for Regional Policy, 1968).

In 1971, the Council Resolution gave a strong incentive to regional development in Common Agricultural Policy (CAP) pursuing a policy of co-ordination of financial aids. After the "Thompson Report" and the enlargement of 1973, the European Regional Development Fund (ERDF) was set up for a 3 -year test period, with the aim to correct regional imbalances.

At the beginning, the operations were purely national, and Member States had to apply for ERDF support at project level, while decisions were then taken in a committee of Member States based on Commission proposals. However, events such as the Single European Act, the Accession of Greece, Spain and Portugal, and the adoption of single market programmes gave a new impetus for a more genuine "European" Cohesion Policy. Indeed, these changes pushed new countries to increase regional disparities-funding as key means of bringing wealth up to EU average and set the basis for the overall framework underlying the Cohesion Policy designed to offset the burden of the single market for the less-favoured regions of the European Community.

In the 1988 for the first time the European Council allocate ECU 64 billion to Struc- 
Table 3: Complementarity and integration between funds in 2014-2020 planning

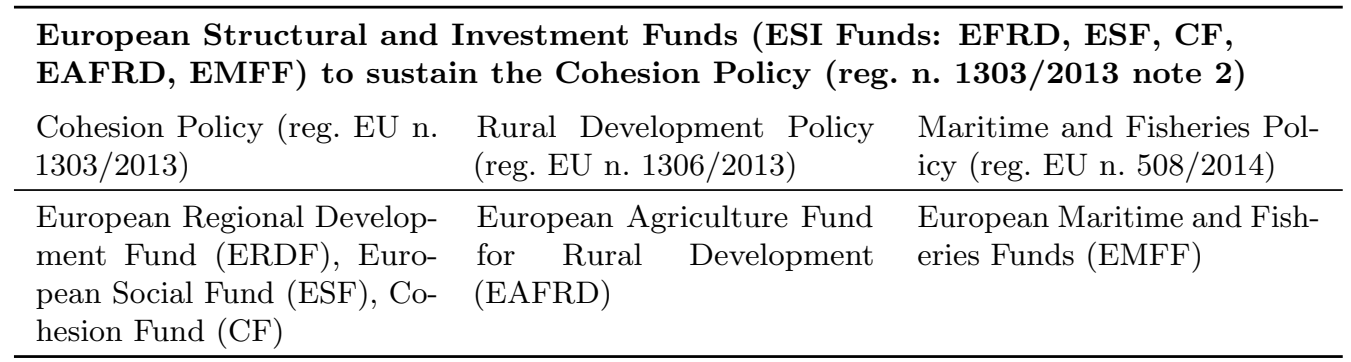

Source: Author's Elaboration on European Commission

tural Funds over 5 years, introducing the following four key principles: i) "concentration" (focusing on poorest regions), ii) "partnership" (involvement of regional and local partners), iii) "programming" (multiannual programming), and iv) "additionality" (of EU expenditure to national ones). This major shift from annual project selection by Member States to a more strategic and multi-annual programming conduced to a wider partnership between regions, Member States and the European Commission and toward a deeper integration of the structural funds around defined priority objectives.

The 1990s saw the standardization of rules, codification of principles of decentralized management and the increase of the structural fund budget from $16 \%$ to nearly $31 \%$ of EU budget. The budget reached ECU 168 billion over 5 years for Structural and Cohesion Funds according to the 1992 EU Treaty.

In the first years of the new millennium, the principle of "efficiency" was introduced to simplify design and procedures, putting the base for the enlargement of May 2004, when ten new Member States joined the Union. The 'Agenda 2000' paved the way for this historic enlargement that brought $20 \%$ increase in the EU population, but only $5 \%$ increase in GDP (EC 2010).

Within the programming cycle 2000-2006, around $€ 195$ billion for the 3 Structural Funds and $€ 18$ billion for the Cohesion Funds were budgeted together with other preaccession instruments for capacity building, rural development, environmental protection and mobility (reg. EU n. 1303/2013). Moreover, the introduction of pre-accession instruments for candidates (ISPA) increased the structural fund budget to $€ 38$ billion per year, reaching about $33 \%$ of EU budget.

For the planning period 2007-2013, the budget increased to about $36 \%$ of the total EU budget, focusing specifically on a growth and jobs strategy but still leaving rural development and fisheries funds outside cohesion policy.

Finally, the planning cycle 2014-2020 not only has been devoting funds for regional and cohesion policy amounting to $€ 351.8$ billion, but it has also introduced an important innovation to favour the integration process, the complementarity and coherence among and within programmes: a unique regulation that sanction general dispositions on the functioning of all the funds (reg. EU n. 1303/2013), and that establish a unique body of funds shared by more policies (the ESI Funds) to implement Unitarian programmes and to align all communitarian policies with the goals of the Europe 2020 strategy (EC 2013).

Nonetheless, it is not easy - especially in places with lower institutional capacities - to be oriented in the complex functioning mechanism of European policies, which are composed by a multitude of strategies, regulations, priorities, funds, and intervention areas. The solution must be found in the complementarity among policies and funds: in the process of local integrated development the complementary has to become a concrete concept, especially when projects and programs are financed by more funds and impact on several local stakeholders.

In other words, better policies (from planning to implementation and evaluation) are needed in weak and marginal territories, described by Rodríguez-Pose (2018, p. 206) as follows: "Policies aimed at maximising the development potential of each territory, solidly grounded in theory and evidence, combining people-based with place-based approaches, and empowering local stakeholders to take greater control of their future". This vision 
is clearly aligned with the perspective of Sustainable Human Development at local level underlying this paper, which has been so far made operational only to a limited extent within the EU Cohesion Policy.

\section{Research design and methodology}

In order to answer the research question underlying this paper, a comparative case-study approach was adopted, by analysing the local development systems of Casentino valley in Tuscany (Italy), Algarve (Portugal) and Corse (France). These case-studies were selected as illustrative examples of marginal and weak territories in Southern Europe - the area with wider regional imbalances within the EU - in geographical and socio-economic terms. Obviously, it should be clarified that findings and arguments derived from this case-study approach can be extended to other similar areas in Europe only to a limited extent, without anyway limiting the relevance of this analysis.

The methodology was based on a harmonic range of different methods, which undoubtedly allowed to diversify the sources of information, digging deeper in all relevant topics and cross-checking findings and results, in order to obtain a comprehensive and consistent picture of the main issues in all areas. The high level of flexibility of the selected method was crucial to tailor them to the relevant target (e.g. different interviewees or group participants), making the whole methodology fully adaptable to the case-studies.

The methodology was mainly characterized by participatory observation and data collection, along with continuous informal and formal interaction with the community and with the main social, economic and political actors. The collection of qualitative data and information was developed in order to let emerge the voice, experiences and "reasons of actions" of all local stakeholders involved in the research. This was also supported by the analysis of secondary data, desk research and literature review in the fields of interest for the inquiry, and in some case by quantitative analysis to support and validate the findings of the qualitative information.

In particular, around 20 face-to-face semi-structured interviews and 4 focus group discusssions were conducted in each area as main data collection methods for our diagnostic analysis of the local development systems. The major goal of the interviews and focus group discussions was to generate a qualitative description to understand the weaknesses and the potentials of the local systems and to identify possible recovery strategy, concrete actions and projects to boost growth and employment in line with the Europe 2020 strategy. While semi-structured interviews had the crucial added-value of allowing to discuss multiple topics, with a certain freedom for the interviewee and interviewer, focus group discussions represented crucial occasions for participatory collective brainstorming to discuss relevant needs and potential solutions. Indeed, focus group discussions allowed the generation of strategic proposals working in interaction and collaboration with specific groups of stakeholders for each chosen territory, by leading participants to share opinions and impressions about the phenomena of interest and by stimulating the production of new ideas and creative proposals.

To conclude, the research followed a process articulated in multiple stages. In general, the procedure included i) identification of place-specific problems / opportunities deserving attention, ii) in-depth understanding of such weaknesses / potentials, iii) discussion of feasible scenarios to overcome such problems and to valorise the endogenous potentials, and iv) extrapolation of useful policy implications for marginal territories in general. In particular, the following steps (with their timing) were followed:

1. Literature review and desk research (02/2014 - 06/2017);

2. Research in Algarve (Portugal): territorial diagnostics, report and results validation $(02 / 2014-06 / 2014)$;

3. Research in Casentino (Italy): territorial diagnostics, report and results validation $(12 / 2014-08 / 2015)$;

4. Research in Corse (France): territorial diagnostics, report and results validation $(04 / 2016-09 / 2016)$;

5. Compartive analysis $(09 / 2016-05 / 2017)$. 
Table 4: Synthetic data on Algarve, Casentino and Corse

\begin{tabular}{lccc}
\hline & Algarve $^{\text {* }}$ & Casentino $^{\circledR}$ & Corse $^{\diamond}$ \\
\hline Administrative level & NUTS II & Sub-NUTS III & NUTS II \\
Main City & Faro & Bibbiena & Ajaccio \\
Main City Inhabitants - 2012 & 62,281 & 12,291 & 66,245 \\
Area (km2) & 4,995 & 700 & 8,680 \\
Population - 2012 & 444,398 & 36,009 & 324,212 \\
Density - 2012 (Inh./km2) & 88.9 & 51.4 & 37.4 \\
Foreign residents - 2012 & $14.1 \%$ & $11.7 \%$ & $9.1 \%$ \\
Old-age dependency ratio $=2012$ & 30,7 & 27,9 & 26,1 \\
GDP per capita - 2012 $(€)$ & 16,774 & 17,372 & 18,730 \\
Unemployment rate - 2012 & $17.9 \%$ & $18.8 \%$ & $10.3 \%$ \\
No. of active firms - 2012 & 58,333 & 3,504 & 46,368 \\
No. of incoming tourists - 2012 & $3,043,920$ & 35,268 & $7,480,800$ \\
\hline
\end{tabular}

Source: *: INE (2013) and CCDR Algarve (2013); ${ }^{\diamond}: \operatorname{ISTAT}(2012) ; \diamond: \operatorname{INSEE}(2014,2015)$

\section{Diagnostic analysis of Local Development Systems}

This chapter briefly presents the results of the territorial diagnostic analysis of the local development systems of Algarve, Casentino and Corse conducted through participatory methods during the field research. The diagnostics have been developed around four main dimensions:

- Habitat (i.e. natural environment and resources, anthropomorphic environment, infrastructural capital and intra/extra local mobility);

- Community $\&$ Ethos (i.e. local and extra-local socio-demographic dynamics, characteristics and trends, local identity, traditions, collective memory, material and immaterial cultural resources, civic participation and involvement in the decisionmaking processes);

- Business (i.e. economic and productive structures, sectorial analyses, occupational needs and employment opportunities);

- Tourism (i.e. endogenous vision, strengths, weaknesses, opportunities, threats, territorial capitals, quantitative analysis of fluxes, project proposals).

For the sake of synthesis, this chapter only presents an integrated assessment of the local development systems, by identifying strategic and critical intervention areas based on the SWOT (Strengths, Weaknesses, Opportunities and Threats) analysis for each territory. 


\subsection{Case-study 1: Algarve}

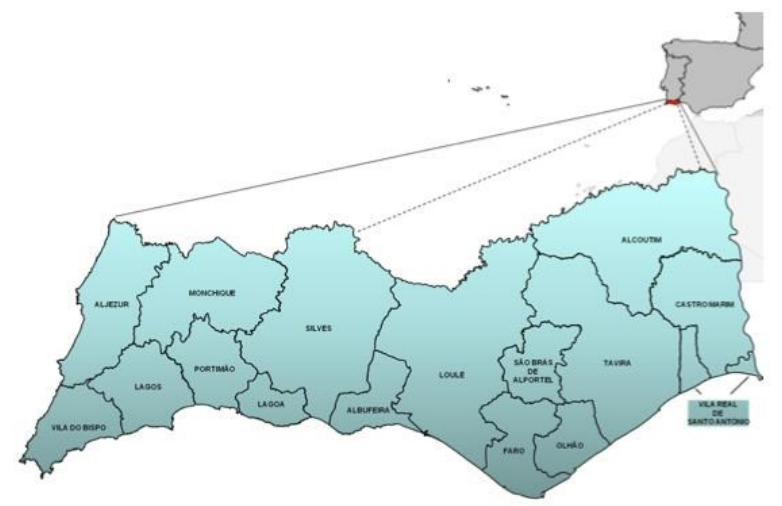

Source: CCDR Algarve (2007)

Figure 1: Algarve in Portugal and Europe

Table 5: Simplified SWOT analysis of Algarve

\section{Strengths}

- Quality and variety of natural resources;

- Airports with international flights and lowcost companies;

- Quality, variety, competitiveness, reputation and consolidation of the touristic sector;

- Other sectors with potential based on resources, existing know-how, in infrastructure and economic dynamics around tourism (e.g. sea, agro-industries, ICT, health or renewable energy).

- High entrepreneurial rate with good spinoff capacity;

- Favourable soil and climate conditions for agricultural activities.

\section{Opportunities}

- Promote diversification and enhancement of the regional economy (including tourism), leveraging other economic activities focused on market niche with high value / potentiality, taking advantage of the dynamics of tourism, of local resources, of available knowledge and capacity;

- Promote the re-industrialization associated with the traditional sectors of the regional economy, boosting employment, generating value added and boosting cooperation networks / knowledge transfer between research centres and the business world.

\section{Weaknesses}

- Atomization and overspecialization on the touristic sector in decline, and high levels of seasonality;

- Levels of unemployment above the national average, accentuated by the negative performance of key regional economic activities;

- Bad transportation system;

- Deficits of leadership and training (individual and collective) and of coordination / cooperation of diverse nature, to enhance critical competitive, critic

- mass and to empower the approach to other dimension markets.

- Difficult to attract FDI and high-skilled workers.

\section{Threats}

- Inability to boost diversification and valorisation of local potentialities;

- Loss of competitiveness and international attractiveness of the Algarve, as a tourist destination or as destinations of investment;

- Inability to boost cooperation networks especially focused on the use of the economic potentials of the region (e.g. networks of cooperation companies, regional innovation system);

- Slow implementation of new energetic sources in the region. 


\subsection{Case-study 2: Casentino}

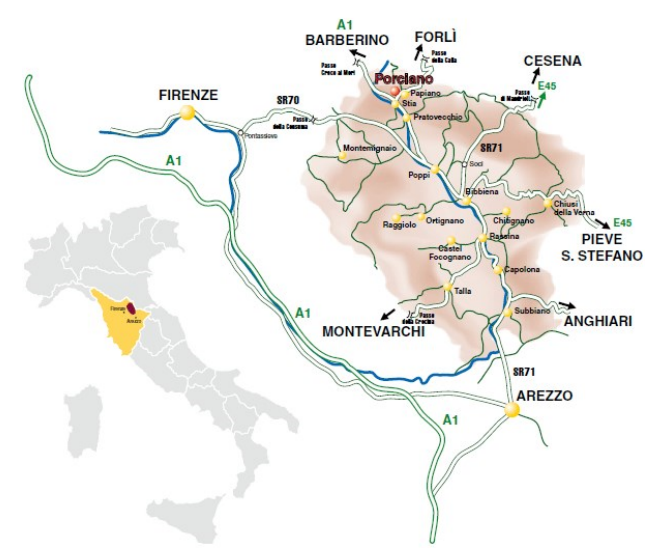

Source: http://www.castellodiporciano.com

Figure 2: Casentino in Tuscany and Italy

Table 6: Simplified SWOT analysis of Casentino

\section{Strengths}

- Natural integrity and wonderful landscapes: important quantity and quality of natural resources and high quality of life;

- Good social capital, high level of social trust, and positive reciprocities' system;

- Ancient craftsmanship knowledge (wood, stone, iron and wool);

- Strong identity and sense of belonging;

- High entrepreneurial rate with good spinoff capacity and high diversification of the economic activity;

- Emergence of new enterprises in ICTs and high value-added sectors and presence of leader companies.

\section{Opportunities}

- Develop effective "feeder system" for public transportation (demand responsive or dial-a-ride public TS), empower the nonmotorized mobility system;

- Exploit the opportunities for social and environmental development / protection through coordination (fund rising) and mutual knowledge (efficiency) among associations;

- Activate synergies and collaborations between different sectors (agro-food-tourism);

- Promote the tourism sector and the proximity with important touristic destinations (Florence, Siena, Rome etc.).

\section{Weaknesses}

- Insufficient mobility system with the population facing barriers to use it (critical situation for nonmotorized mobility);

- Very marked ageing dynamic and negative natural growth rate of the population, youth emigration;

- Very weak and fragmented governance systems;

- Reduction of important historical production chains (textile, wood, agro-forestrypastoral)

- Difficulties to attract high-skilled workers and FDI;

- Relative isolation of the area, scarce accessibility and lack of telematics networks, scarce services' supply.

\section{Threats}

- Hydrogeological risk and instability (ecosystemic disequilibria);

- Closeness to the outside world could generate exclusion phenomena, tensions and conflicts;

- Progressively ageing population, higher incidence of social and productive problems;

- Emigration of younger generations and difficulties in inter-generational passages;

- The economic crisis and the bankrupt of important enterprises and territorial banks: risk of financial and economic contagion and troubles.

Source: Author's elaboration 


\subsection{Case-study 3: Corse}

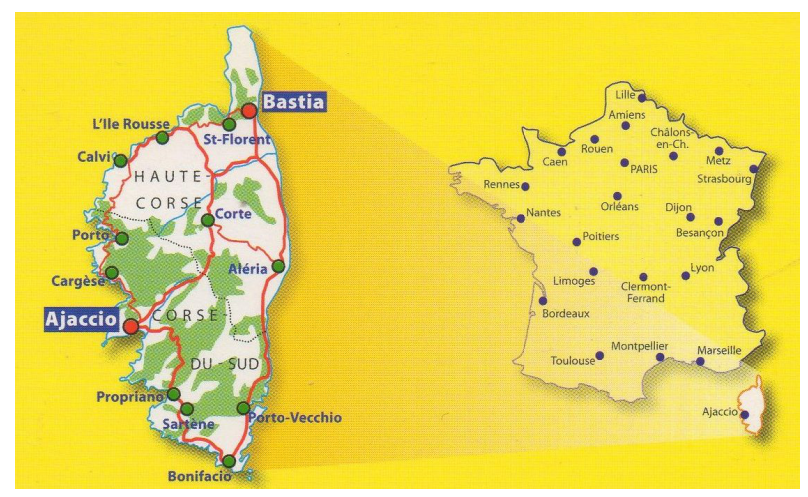

Source: http://www.mapsman.com

Figure 3: Corse in France

Table 7: Simplified SWOT analysis of Corse

\section{Strengths}

- Quality and variety of natural resources, wonderful landscapes, high quality of life;

- Diffused cultural, architectonical and natural heritage;

- Quality, variety, competitiveness, reputation and consolidation of the touristic sector;

- Undiscovered, unexplored and secret place different from the national context (speculated in the collective imaginary, and in touristic marketing);

- Strong identity and sense of belonging;

- Consolidated market in primary sector;

- Persistence of cultural traditions and craftsmanship knowledge;

- Airports with international flights and lowcost companies.

\section{Opportunities}

- Empower non-motorized mobility system and develop effective "feeder system" for public transportation;

- Activate synergy and collaboration between different sectors to generate important economies of scale and scope (agrofood-tourism);

- Create integrated local production chains (agro-food-tourism);

- Opportunity for the de-seasonality of the touristic demand (snow, ski, chestnuts, etc.) and to create attractive touristic packages in all seasons.

\section{Weaknesses}

- Bad transportation system;

- Progressively ageing population, higher incidence of social and productive problems;

- Reduction of important historical production chains (tannin, wood, agro-forestrypastoral)

- Levels of unemployment above the national average;

- Very marked ageing dynamic of the population, negative natural growth rate of the population and youth emigration create difficulties in the intergenerational turnover, and weaken the local community;

- Small Enterprises highly dependent on the national market and with scarce entrepreneurial culture.

\section{Threats}

- Hydrogeological risk and instability;

- Slow implementation of new energetic sources in the region;

- Insane forest expansion as consequence of agropastoral activities reduction;

- Resistance to changes by older generation, and little openness to innovation;

- Losses of knowledge and know-how in important sectors (wood, textile) and disappearance of important artisanal activities (wood, stone, iron, wool);

- Progressively ageing population, higher incidence of social/productive problems.

Source: Author's elaboration 


\subsection{Comparative findings}

The population dynamics of these territories had been strongly negative till the 1980s, since then they have continued with a stable trajectory till the present day. It seems that, despite the losses of human capital, these local systems have found dynamic equilibriums.

The primary resource of these three territories is in their environmental, natural and cultural richness. Despite the huge amount of natural and cultural resources, people living in such territories face important problems and barriers to access essential services (e.g. education, health) as well as in terms of internal and external mobility.

Therefore, a primary precondition to tap into untapped potential and to provide wider socio-economic opportunities to the people living in those places is to increase the spatial accessibility and the services usability. In particular, to stop the abandonment dynamics of the local population and to create conditions for the younger generations to live and build their future in these areas, it is essential to enhance the quality and accessibility of basic services for the resident people, guaranteeing essential services such as high quality educational supply for the youths, adequate health care assistance, and create employment opportunities. In fact, one of the main economic weaknesses of these areas seems to be their infrastructural endowments. On the one hand, the low level of internal infrastructural development is undoubtedly a comparative disadvantage for many local businesses, which are penalised in term of transportation costs. This has also led to a relevant fragmentation and atomization of the entrepreneurial base in these areas, with limited economies of scale and learning. On the other hand, this low level of infrastructural endowment may have created a competitive advantage in terms of territorial / landscape distinction with respect to the regional and national contexts, having also limited the diffusion of external (and often cheaper) products.

Moreover, the above-mentioned economic fragmentation is also reflected at institutional and governance levels, with a wide number of public entities having diversified (and sometimes overlapping) responsibilities in decision-making, policy design and public administration.

Finally, these areas share the potential for strategies based on their attractiveness in terms of sustainable tourism destinations and on the quality of their agro-food production, being both characterised by elements of cultural tradition, integrity and respect for the environment.

\section{Policy implications for Mediterranean marginal territories}

The diagnostic analysis of Casentino, Algarve and Corse local development systems, which could be taken as reference territories for other similar areas in Europe, together with the analysis of the European policy framework for marginal areas stimulates a reflection on the marginal conditions of such territories leading to a more general overview of the possible development trajectories, scenarios and conditions that could be applied in other territorial contexts.

The territory is not an enterprise, thus, it cannot close for bankruptcy. It could be depopulated of people and activities, but the territory cannot close and die. Therefore, a place-based and people-centred approach to territorial development makes sense only in a policy framework open to the evolution and integration of multiple models, strategies, and development trajectories.

In order to foster their development processes, it is primarily necessary to reduce the marginality through accessibility: basic services (education and health care), spatial and virtual accessibility. Accessibility means to allow person to live, host, travel, build social relations, develop businesses and create jobs and wealth. Therefore, in order to create the conditions for a real contribution of such areas to the overall development of the European Union, it is necessary to implement strategies to protect and enjoy their citizenship rights, and to sustain the local (and thus national and European) economic growth starting from their untapped endogenous potential.

According to the previous analysis and considerations, a crucial condition to overcome the territorial weakness of many European local development systems is to "open" the local context itself. 
The openness of marginal territory could be conceived as:

- Openness to external resources: financial resources (e.g. European Funds) and innovation leverages, such as universities or R\&D centres (Noronha Vaz, Cesário 2005);

- Institutional openness through the application of multilevel governance models among different administrative levels;

- Construction of inter-municipal, trans-regional and trans-national cooperation networks, which could assume different forms and allow good practice exchanges and formative experiences of territorial programming, management and development among local administrations, technicians and administrators;

- Openness to global markets through internet and technological innovations (Noronha Vaz, Cesário 2005).

Thus, the uniqueness of a territorial system has to be included in a broader set of translocal network relations, however, this could weaken and threaten the same uniqueness that characterizes the local system. For instance, in many cases territorial development practices are focused on the valorisation of the historical-cultural-environmental heritage in touristic terms, placing much effort on tourism promotion and valorisation. However, often such interventions aim at homologating the local attractiveness around folkloristic images built on a presumed local identity, or around alternative emergent touristic segments (agro-tourism, cultural tourism, rural development, etc.).

Another condition concerns capacities and opportunities, in the sense of assimilation and application of the knowledge and skills that empower people to purse their aspirations, businesses to pursue their objectives, institutions to pursue local development and wellbeing. From this perspective it makes sense to think that a territory could acquire the functioning to express new, complementary and sustainable development models (Biggeri, Ferrannini 2014), offering its own contribution to the external world instead of being conceived as "places that don't matter". This broad capacity-building condition includes for instance:

- To promote knowledge and know-how production, diffusion and reproduction, starting from local embedded knowledge, and encouraging and investing in research and development activities aiming at finding new and innovative way to foster socio-economic development;

- Construction of socio-economic and productive networks, in the sense of industrial districts and clusters (Becattini et al. 2009) based on cooperation-competition mechanisms among local SMEs and other local stakeholders.

The acquisition of planning, operative, cooperative and governance capacities at the local level could contribute to change the defining parameters of territorial marginality and weakness. In addition to structural socio-economic factors, they give importance to the capacity to react to top-down stimulus and promoting their own strategic and enlarged development vision.

In addition, another condition is the enhancement of social capital and trust in the possibility to act in a situation of scarce resources. It is necessary to believe and stimulate the changing of the local entrepreneurs and administrators' behaviours in order to jointly exploit economies of learning and scope for the local system. In this regard, it appears relevant to:

- Enhance the governance system and its administrative processes, through the improvement of the social dialogue, the capacity to elaborate, collaborate, share, and co-act, posing a primary goal for collective wellbeing, but recognizing the interdependence of individual development trajectories (Sen 2009).

- Sustain the valorisation of endogenous territorial and cultural capital, as the local identity has a dynamic value with respect to history, traditions, and knowledge. Therefore, it is necessary to activate participatory processes able to trigger the sense of belonging for a development path (Biggeri, Ferrannini 2014, Biggeri et al. 2018). 
Finally, as we have seen, the core of the current communitarian policies is the promotion of smart, inclusive and sustainable growth, which makes reference to a unique development framework where cohesion and sustainability are functional to these priorities.

In order to embrace the territorial dimension of policies, it is thus necessary to re-start from the territories, utilizing an operative and realistic approach, which could take into account the relevant issues, the priorities of development strategies and the various forms of internal and external collaboration and partnerships.

\section{Final Remarks}

The centrality and specificity of the territory and its resources has changed the view on local development paradigms: it is not yet acceptable to consider a unique direction where localities have to converge, at the same way, and it does not make sense to consider a universal model which represent a prototype of developed society; instead, there is a multiplicity of local models. The destiny of marginal areas is not to converge with developed ones, but to take their own unique irreproducible trajectory.

Nonetheless, local development and cohesion policies at national and European level have not been adequate in the last years to tackle the challenges they face. Many European territories are far from overcoming their own structural weaknesses and deficits to build the base for the flourishing of the endogenous potential. The affirmation of certain local development models and the valorisation of endogenous resources are very complex processes, which have to face the reality of challenges based on: the real potential of a territory, the real predisposition of local actors, the internal and external real demand, the extra-local programming context, and the global dynamics.

On these premises, marginal territories can (and should) play a fundamental role in ensuring equilibrium, cohesion and sustainability in the European development process. Although the territorial dimension in the process of European policies and scenarios is increasingly marked, this does not imply that marginal territories themselves are conscious to be part of such scenarios. It is clear that Europe is perceived, at the local context, mainly as a potential source of funds, but also as imposing constraints, recently leading to increased populism and anti-Europe feelings.

Therefore, analysing territorial unbalances from the perspective of marginal territories could be a way to check if there are intersections between communitarian scenarios and territorial realities. The European territorial development scenarios are defined by priorities and political choices that aim to react to the main global challenges, but it seems crucial to design development processes to be tailored on the territories and through the territories themselves. Specifically, marginal territories provide development issues, models and opportunities that deserve to be taken into account within European and national policy-making and instruments provision.

The potentials of marginal territories to contribute to harmonious development process within the EU may consist in a series of elements such as: the design and pursuit of their own local development trajectories; the construction of extra-local, trans-regional and trans-European networks; the operationalization of the development principles (sustainability, cohesion, polycentrism, competitiveness, etc.); the closeness to the needs and aspirations of citizens; the tailored adaption of extra-local strategies.

Moreover, the development processes and practices in marginal territories (which start from worse conditions) could allow territories and their actors to acquire a superior consciousness of their own active roles, to be able to directly contribute to the local, national and European development and to define new complementary forms of polycentrism with respect to the global ones. Thus, they can contribute developing their own conditions and becoming conscious to be part of an enlarged system, opening up to external resources, global markets, in institutional terms and in the construction of multilevel cooperation and socio-economic productive networks.

In other words, marginal territories could provide innovative people-centred and place-based conceptualizations and operationalizations of the core development ideas and models underlying the European Union. Although there is no guarantee that their contribution will be successful, this people-centred and place-based approach seems to 
offer the best option to enhance the capabilities of people and communities to flourish within a sustainable human development perspective.

\section{References}

Amin A (1999) An institutionalist perspective on regional economic development. International Journal of Urban and Regional Research 23[2]: 365-378. CrossRef.

Barca F (2009) An agenda for a reformed cohesion policy: A place-based approach to meeting European Union challenges and expectations. Independent report prepared at the request of the European Commissioner for regional policy, Danuta Hübner, European Commission, Brussels

Barca F, McCann P, Rodriguez-Pose A (2012) The case for regional development intervention: Place-based versus place-neutral approaches. Journal of Regional Sciences 52[1]: 134-152. CrossRef.

Becattini G (2001) Metafore e vecchi strumenti: Ovvero delle difficoltà d'introdurre il 'territorio' nell'analisi socio-economica. In: Becattini G, Bellandi M, Dei Ottati G, Sforzi F (eds), Il Caleidoscopio dello sviluppo locale. Trasformazioni economiche nell'Italia contemporanea. Rosenberg \& Sellier, Turin

Becattini G (2014) Prologue. In: Biggeri M, Ferrannini A (eds), Sustainable Human Development: A New Territorial and People-Centred Perspective. Palgrave Macmillan, London

Becattini G, Bellandi M, De Propris L (2009) A handbook of industrial districts. Edward Elgar Publishing, Cheltenham. CrossRef.

Biggeri M, Ferrannini A (2014) Sustainable Human Development: A New Territorial and People-Centred Perspective. Palgrave Macmillan, Basingstoke and New York. CrossRef.

Biggeri M, Ferrannini A, Arciprete C (2018) Local communities and capability evolution: The core of human development processes. Journal of Human Development and Capabilities 19[2]: 126-146. CrossRef.

Bolton R (1992) 'place prosperity vs people prosperity' revisited: An old issue with a new angle. Urban Studies 29[2]: 185-203. CrossRef.

CCDR Algarve - Comissão de Coordenação e Desenvolvimento Regional do Algarve (2007) Plano Regional de Ordenamento do Território do Algarve - PROTAlgarve. Comissão de Coordenação e Desenvolvimento do Algarve, Faro

CCDR Algarve - Comissão de Coordenação e Desenvolvimento Regional do Algarve (2013) Algarve Preparar o Futuro, Diagnóstico Prospetivo 2014-2020. Comissão de Coordenação de Desenvolvimento Regional, Faro

Crescenzi R, Rodríguez-Pose A (2011) Reconciling top-down and bottom-up development policies. Environment and Planning 43[4]: 773-780

Dematteis G (2013) La montagna nella strategia per le aree interne 2014-2020. Agriregionieuropa 34

EC - European Commission (2010) Europe 2020: A strategy for smart, sustainable and inclusive growth. $\operatorname{COM}(2010) 2020$ final, Brussels

EC - European Council (2013) Laying down the multiannual financial framework for the years 2014-2020. No 1311/2013 of 2 December 2013, OJ L 347, 20.12.2013, p. 884-891

EU - European Union (2011) Territorial agenda of the European Union 2020. Towards an inclusive, smart and sustainable Europe of diverse regions. agreed at the Informal Ministerial Meeting of Ministers responsible for Spatial Planning and Territorial Development on 19th May 2011 Gödöllö, Hungary 
INE - Instituto Nacional de Estatística (2013) Anuário Estatístico da Região do Algarve 2012. Instituto Nacional de Estatística, Lisboa

INSEE - Institut National de la Statistique et des Etudes Economiques (2014) Annual national accounts. Institut National de la Statistique et des Etudes Economiques, Paris

INSEE - Institut National de la Statistique et des Etudes Economiques (2015) Gross domestic product (GDP) and main economic aggregates. Institut National de la Statistique et des Etudes Economiques, Paris

ISTAT - Istituto Statistico Nazionale (2012) 15 censimento della popolazione e delle abitazioni, struttura demografica e familiare della popolazione residente. Istituto Statistico Nazionale, Roma

Marks G (1996) An actor-centred approach to multi-level governance. Regional and Federal Studies 6[2]: 20-40. CrossRef.

Noronha Vaz T, Cesário M (2005) Behavioural patterns towards innovation: the case of European rural regions. Proceedings of XVI ISPIM Conference: Porto, Portugal - The Role of Knowledge in Innovation Management - ISBN 952-214-059-7

Piattoni S (2010) The Theory of Multi-Level Governance. Conceptual, Empirical, and Normative Challenges. Oxford University Press, Oxford

Pike A, Rodríguez-Pose A, Tomaney J (2007) What kind of local and regional development and for whom? Regional Studies 41[9]: 1253-1269. CrossRef.

Raffestin C (1980) Pour une géographie du pouvoir. éd LITEC, Paris

Rodríguez-Pose A (2018) The revenge of the places that don't matter (and what to do about it). Cambridge Journal of Regions, Economy and Society 11[1]: 189-209. CrossRef.

Rodríguez-Pose A, Crescenzi R (2008) Mountains in a flat world: Why proximity still matters for the location of economic activity. Cambridge Journal of Regions, Economy and Society 37[1]: 1-18. CrossRef.

Sen AK (1999) Development as Freedom. Oxford University Press, Oxford. CrossRef.

Sen AK (2009) The idea of justice. Allen Lane, London

Storper M (1997) The Regional World: Territorial Development in a Global Economy. Guilford Press, New York

UNDP - United Nations Development Programme (1990) Human Development Report 1990 - Concept and measurement of human development. Oxford University Press, New York

cc) () (-) (c) 2019 by the authors. Licensee: REGION - The Journal of ERSA, European Regional Science Association, Louvain-la-Neuve, Belgium. This article is distributed under the terms and conditions of the Creative Commons Attribution, Non-Commercial (CC BY NC) license (http://creativecommons.org/licenses/by-nc/4.0/). 